\title{
Cloning and Expression of a Queen Pheromone-Binding Protein in the Honeybee: an Olfactory-Specific, Developmentally Regulated Protein
}

\author{
Emmanuelle Danty, ${ }^{1}$ Loïc Briand, ${ }^{2}$ Christine Michard-Vanhée, ${ }^{3}$ Valérie Perez, ${ }^{2}$ Gérard Arnold, ${ }^{1}$ \\ Odile Gaudemer, ${ }^{2}$ Dominique Huet, ${ }^{3}$ Jean-Claude Huet, ${ }^{2}$ Christian Ouali, ${ }^{2}$ Claudine Masson, ${ }^{1}$ and \\ Jean-Claude Pernollet ${ }^{2}$ \\ ${ }^{1}$ Centre Européen des Sciences du Goût, Centre National de la Recherche Scientifique (CNRS), Unité "Olfaction, \\ Gustation, Nutrition," 21000 Dijon, France, 2Unité de Recherches de Biochimie et Structure des Protéines, Institut \\ National de la Recherche Agronomique Unité Recherche 477, 78352 Jouy-en-Josas Cedex, France, and ${ }^{3}$ Neurobiologie \\ Expérimentale et Théorie des Systèmes Complexes, CNRS Unité Propre de Recherche 9081, 75231 Paris \\ Cedex 05, France
}

\begin{abstract}
Odorant-binding proteins (OBPs) are small abundant extracellular proteins thought to participate in perireceptor events of odor-pheromone detection by carrying, deactivating, and/or selecting odor stimuli. The honeybee queen pheromone is known to play a crucial role in colony organization, in addition to drone sex attraction. We identified, for the first time in a social insect, a binding protein called antennal-specific protein 1 (ASP1), which binds at least one of the major queen pheromone components. ASP1 was characterized by cDNA cloning, expression in Pichia pastoris, and pheromone binding. In situ hybridization showed that it is specifically expressed in the auxiliary cell layer of the antennal olfactory sensilla. The ASP1 sequence revealed it as a divergent member of the insect OBP family. The recombinant protein presented the exact characteristics of the native protein, as shown by mass spectrometry,
\end{abstract}

In insects and vertebrates, hydrophobic odorants are thought to be transported and/or inactivated in an aqueous phase bathing dendrites of olfactory receptor neurons, by small water-soluble extracellular proteins, the odorant-binding proteins (OBPs) (Pelosi, 1994). In insects, the pheromone-binding proteins (PBPs) involved in mate attraction have been distinguished from other OBPs, the general odorant-binding proteins (gOBPs) (Vogt et al., 1991). Several PBPs and gOBPs have generally been found in the same species (Pelosi, 1994). They present different binding specificities and/or associate with different olfactory neuron types, at least for PBPs, suggesting that they may play an additional role in olfactory coding (Pelosi and Maida, 1995). PBPs have been extensively studied in the moth specialist system for sex pheromone detection, whereas gOBPs appear to be involved in the detection of other odorants by the generalist system in the fruit fly (Kim et al., 1998).

The honeybee is able to discriminate a wide range of odorants

Received April 1, 1999; revised June 11, 1999; accepted June 18, 1999.

This work was supported by the French Centre National de la Recherche Scientifique, the Association pour la Recherche contre le Cancer, and the Institut National de la Recherche Agronomique. We are grateful to C. Papin and J. F. Odoux for technical assistance and I. Jakob for helpf ul comments.

Correspondence should be addressed to Emmanuelle Danty, Centre Européen des Sciences du Goût, Centre National de la Recherche Scientifique, Unité "Olfaction, Gustation, Nutrition,” 15 rue Hugues Picardet, 21000 Dijon, France.

Copyright (C) 1999 Society for Neuroscience $\quad 0270-6474 / 99 / 197468-08 \$ 05.00 / 0$ and $\mathrm{N}$-terminal sequencing and exclusion-diffusion chromatography showed that recombinant ASP1 is dimeric. ASP1 interacts with queen pheromone major components, opposite to another putative honeybee OBP, called ASP2. ASP1 biosynthetic accumulation, followed by nondenaturing electrophoresis during development, starts at day 1 before emergence, in concomitance with the functional maturation of olfactory neurons. The isobar ASP1b isoform appears simultaneously to ASP1a in workers, but only at $\sim 2$ weeks after emergence in drones. Comparison of in vivo and heterologous expressions suggests that the difference between ASP1 isoforms might be because of dimerization, which might play a physiological role in relation with mate attraction.

Key words: queen pheromone; binding protein; olfaction; antenna; sensilla; honeybee; Pichia pastoris expression and thus constitutes an attractive experimental model for comparative analyses of the molecular and cellular mechanisms underlying general odor detection between insects and vertebrates (Masson and Mustaparta, 1990; Masson et al., 1993; Hildebrand and Shepherd, 1997). Moreover, the dual property of queen pheromone, which both acts as a sex attractant for drones and controls numerous activities of workers to maintain colony cohesion and stability (Free, 1987), allows investigation as to whether such an odor is specifically encoded by a specialist system or not, and how.

Many of the behavioral effects of the queen mandibular gland pheromone are induced by a synthetic blend of five major compounds (Slessor et al., 1988). For drones, 9-keto-2(E)-decenoic acid (9-ODA) and 9-hydroxy-2(E)-decenoic acid (9-HDA) are the most active components in both behavioral assays (Free, 1987) and electrophysiological recordings of receptor cells (Brockman et al., 1998). Drones are much more sensitive to 9-ODA than workers, suggesting that they possess more sensory neurons responding to this molecule (Adler et al., 1972).

Search of honeybee OBPs was initiated a few years ago, leading to identification of three subclasses of antennal-specific proteins (ASPs), namely ASP1, ASP2, and ASP3 (Danty et al., 1997, 1998). Based on sequence similarity and tissue specificity, ASP2 was assigned to be a member of the insect OBP family and the ASP3 subclass to belong to another family of olfactory proteins 
(McKenna et al., 1994; Pikielny et al., 1994; Maleszka and Stange, 1997). Because of probable association of gOBPs and PBPs with neurons sensitive to general odors and to sex pheromone, respectively, ASP1 has been proposed to be associated with queen pheromone detection because of its higher abundance in drone, inverse to ASP2, supposed to interact with other odorants (Danty et al., 1998).

In this study, we further characterized ASP1 by molecular cloning and analysis of tissue location and functional properties of the heterologous expressed protein in concordance with in vivo expression.

\section{MATERIALS AND METHODS}

Molecular cloning and sequencing. A $5^{\prime}$ extension primer (5'GTGGATCC[C/T]GA[A/G]GTITT[C/T]GA[C/T][C/T]TIGTIGC) was deduced from the peptide PEVFDLVA selected in the ASP1 N-terminal sequence (Danty et al., 1998). It was used for rapid amplification of cDNA ends (RACE) $3^{\prime}$-specific amplification, and the $3^{\prime}$ primer was 5'GAGAGAACTAGCTCGAGTT. RACE 3' amplification was performed on adult drone antennal cDNA prepared as described by Danty et al. (1997). Specific amplifications were performed in $1.5 \mathrm{~mm} \mathrm{MgCl}_{2}$, $0.2 \mathrm{~mm}$ dNTPs, $1 \mathrm{pm}$ each primer (Eurogentec, Seraing, Belgium), 0.5 $\mathrm{U} / 100 \mu \mathrm{l}$ Goldstar Taq (Eurogentec), and first strand cDNA equivalent to $60 \mathrm{pg}$ of poly $(\mathrm{A}+) \mathrm{mRNA}$. Amplification cycles were $5 \mathrm{~min}$ at $95^{\circ} \mathrm{C}, 5$ min at $50^{\circ} \mathrm{C}$, and $20 \mathrm{~min}$ at $72^{\circ} \mathrm{C}$ for five cycles; $40 \mathrm{sec}$ at $95^{\circ} \mathrm{C}, 1 \mathrm{~min}$ at $50^{\circ} \mathrm{C}$, and $1 \mathrm{~min}$ at $72^{\circ} \mathrm{C}$ for 40 cycles; and $15 \mathrm{~min}$ at $72^{\circ} \mathrm{C}$ for one cycle. After purification, the PCR amplification product was labeled by DIGDNA random priming (Boehringer Mannheim, Meypan, France).

Approximately 750 antennae were sectioned from Apis mellifera adult drones anesthetized by cooling at $-20^{\circ} \mathrm{C}$ for a few minutes. Poly $(\mathrm{A}+)$ mRNAs were purified by using the standard protocol of the Quick mRNA Purification Kit (Amersham Pharmacia Biotech, Saclay, France). A cDNA library of $3 \times 10^{7}$ primary recombinants was generated and then amplified at $4 \times 10^{8} \mathrm{pfu} / \mathrm{ml}$, using the $\lambda \mathrm{ZAP}$ II cDNA library synthesis kit as described by the manufacturer (Stratagene, La Jolla, CA). This library was screened with the digoxigenin-DNA labeled probe according to the standard procedure. After a secondary screening step, clones of interest were submitted to double-stranded sequencing with internal primers by Eurogentec custom service.

Sequence analysis. Sequence similarity with known proteins was searched with Basic Local Alignment Search Tool computed at the National Center of Biotechnology Information (NCBI) (Altschul et al., 1990; Gish and Strates, 1993). Percentages of amino acid sequence identity were calculated by using a Blosum 50 matrix (Myers and Miller, 1988). A verification of protein sequence homology was performed by using Block Searcher (Henikoff and Henikoff, 1994) from ASP1 peptide, and the best matching group of proteins deduced was used to construct an alignment between ASP1 and the group of sequences that the blocks represent.

In situ hybridization procedure. $\mathrm{T} 3$ and $\mathrm{T} 7$ polymerases were used to generate sense and antisense DIG-labeled 11UTP RNA probes (Boehringer Mannheim) from linearized cDNA clone 11M8A1. The procedure of in toto hybridization on adult bee antennae was performed as described previously (Danty et al., 1997).

Electrophoresis of sex- and age-selected protein extracts. Honeybees were raised under natural conditions and studied during nymphal and adult development. After $3 \mathrm{~d}$ of embryonic development, the duration of postembryonic development, composed of larval and pupal stages, is $\sim 18$ $\mathrm{d}$ for the worker and $21 \mathrm{~d}$ for the drone (Jay, 1963). For an exact determination of the age of worker pupae, the queen of a colony was restricted to one comb for several hours. Starting at $14 \mathrm{~d}$ after the laying, e.g., $7 \mathrm{~d}$ before the emergence of the adult $(\mathrm{E}-7)$, pupae were collected daily (since $\mathrm{E}-7$ to $\mathrm{E} 0$ ). Drone fifth instar larvae, prepupae, and pupae since $\mathrm{E}-10$ to $\mathrm{E} 0$ were collected since $\mathrm{E}-9$ to $\mathrm{E} 0$ from combs containing drone brood of varied ages. Their precise age was determined by the colors of the compound eyes and the thorax (Rembold et al., 1980). Age-selected worker and drone adults were obtained by labeling emerging insects with a dot of painting on the thorax and maintained under natural conditions in the hive until they reached the required age. Foragers, which were older than 2-week-old, were caught at the entrance of the hive.

Antennal protein extracts were prepared as described previously (Danty et al., 1998). Protein analysis was performed by nondenaturing electrophoresis adapted from Laemmli (1970) in a 16.8\% acrylamide gel and separated in $2.5 \mathrm{hr}$ at $250 \mathrm{~V}$. Proteins were stained with a colloidal Coomassie blue-R (Serva Feinbiochemica, Heidelberg, Germany) $0.035 \%$ solution in $12 \%$ trichloroacetic acid and $5 \%$ ethanol and destained in water.

Expression of ASP1 by Pichia pastoris. The cDNA clone 11M8A1 encoding the native precursor ASP1 was amplified by PCR using the following primers: the 5' primer, 5'TTACGCGAATTCACCATGGTTAGCAACACGAAG and the $3^{\prime}$ primer, 5'CGTCGCGAATTCTTAGATAACGAACCATAC allowing the creation of a Kozak consensus sequence and the restriction sites. The PCR-amplified fragment was cloned into the EcoRI site of pHIL-D2 shuttle vector from Invitrogen (The Netherlands). The correct orientation of the DNA insert was determined by PCR using the $5^{\prime} A O X 1$ primer from Invitrogen and the $3^{\prime}$ primer described above. The sequence of the construction was confirmed by dideoxy chain termination sequencing.

For transformation, the expression plasmid was linearized with Not I and later transferred into the Pichia pastoris yeast host through the spheroplasting method as described in the manual (version 3.0) of the Pichia expression Kit (Invitrogen). The selection of secreting clones, the culture production, and the protein purification of recombinant ASP1 have been achieved as described previously for the expression of recombinant ASP2 (Briand et al., 1999).

Characterization of the recombinant ASP1. SDS-PAGE (16\% acrylamide) was performed using a Mini-Protean II system (Bio-Rad, Ivrysur-Seine, France) according to the method of Schägger and von Jagow (1987) with modification (Sallantin et al., 1990). The molecular weight calibration kit PMW (Pharmacia, Saclay, France) was used, and the proteins were visualized by Serva Feinbiochemica blue-G staining. Recombinant ASP1 was also submitted to nondenaturing electrophoresis in $12.8 \%$ acrylamide gel. Microion spray-mass spectrometry (IS-MS) and $\mathrm{N}$-terminal amino acid sequence analyses were performed as described previously (Briand et al., 1999). To quantify the extent of free thiols of recombinant ASP1, the colorimetric reaction using 5,5'-dithiobis (2nitrobenzoic acid) developed by Ellman (1958) was performed. Tenfold excess of Ellman's reagent over protein was used, and the number of reactive cysteine residues was quantified by following the absorbance at $412 \mathrm{~nm}$.

The molecular mass of the recombinant ASP1 was evaluated by exclusion-diffusion chromatography on a $24 \mathrm{ml}$ bed volume Superose 12 column (Pharmacia) equilibrated in $100 \mathrm{~mm}$ potassium phosphate and $150 \mathrm{~mm} \mathrm{NaCl}, \mathrm{pH} 7.5$, at $0.5 \mathrm{ml} / \mathrm{min}$. Bovine serum albumin, chicken egg ovalbumin, bovine ribonuclease $\mathrm{A}$, bovine $\alpha$-chymotrypsinogen $\mathrm{A}$, and horse cytochrome $c$ (Sigma) were used as standards. A $100 \mu$ l sample of purified ASP1 was loaded at $1.0 \mathrm{mg} / \mathrm{ml}$ onto the Superose column, and the elution profile was obtained from on-line UV detection at $280 \mathrm{~nm}$.

Pheromone binding test. Recombinant ASP2 and capsicein were purified as described previously by Briand et al. (1999) and Pernollet et al. (1993), respectively. Bovine $\alpha$-lactalbumin was obtained from Sigma. The synthetic blend corresponding to the major components of the queen bee mandibular gland extract was purchased from Phero Tech Inc. (Delta, Canada). It is composed of 9-ODA $(150 \mu \mathrm{g}), 9-\mathrm{HDA}(71 \%$ $\mathrm{R}-(-), 29 \% \mathrm{~S}-(+) ; 55 \mu \mathrm{g})$, methyl $p$-hydroxybenzoate $(13 \mu \mathrm{g})$, and 4-hydroxy-3-methoxyphenylethanol $(1.5 \mu \mathrm{g})$ as defined for one queen equivalent (Qeq), the average amount of pheromone found in the gland of mated queen (Slessor et al., 1988). The synthetic pheromone blend was dissolved in ethanol to a final concentration of $10 \mathrm{mg} / \mathrm{ml}$. Purified ASP1 and the other proteins were dissolved in $250 \mu \mathrm{l}$ of $200 \mathrm{~mm}$ ammonium hydrogen carbonate, $\mathrm{pH} 7.5$, buffer to a final concentration of $0.46 \mathrm{~mm}$ and incubated overnight at $25^{\circ} \mathrm{C}$ with $5 \mu$ of the synthetic pheromone solution with slow agitation. The proteins were then precipitated by adding $3 \mathrm{ml}$ of ice-cold ammonium sulfate at saturation and centrifuged at $15,000 \times g$ for $30 \mathrm{~min}$ at $4^{\circ} \mathrm{C}$. The pellets were washed two times using $1 \mathrm{ml}$ of saturated ammonium sulfate. After resuspension into $3 \mathrm{ml}$ of MilliQ (Millipore, St. Quentin-en-Yvelines, France) $\mathrm{H}_{2} \mathrm{O}$, the pellets were then extracted at room temperature with $3 \mathrm{ml}$ of chloroform. After evaporation of the solvent phase, the ligand was methylated $48 \mathrm{hr}$ at room temperature with $3 \mathrm{ml} \mathrm{BF3} \mathrm{(14 \%} \mathrm{in} \mathrm{methanol)} \mathrm{and} \mathrm{analyzed} \mathrm{by} \mathrm{gas}$ chromatography using a GC 8000 Series 8180 Fisons Instruments (Thermoquest, Herts, UK) equipped with an on-column injector and flame ionization detector $\left(300^{\circ} \mathrm{C}\right)$. The analytical column used was a DB-1 column $30 \mathrm{~m} \times 0.32 \mathrm{~mm}$, inner diameter $0.25 \mu \mathrm{m}$ (J\&W Scientific, Folsom, CA), with a deactivated precolumn. The oven temperature gradient applied was from 60 to $200^{\circ} \mathrm{C}$ at $10^{\circ} \mathrm{C} / \mathrm{min}$ and then raised to 


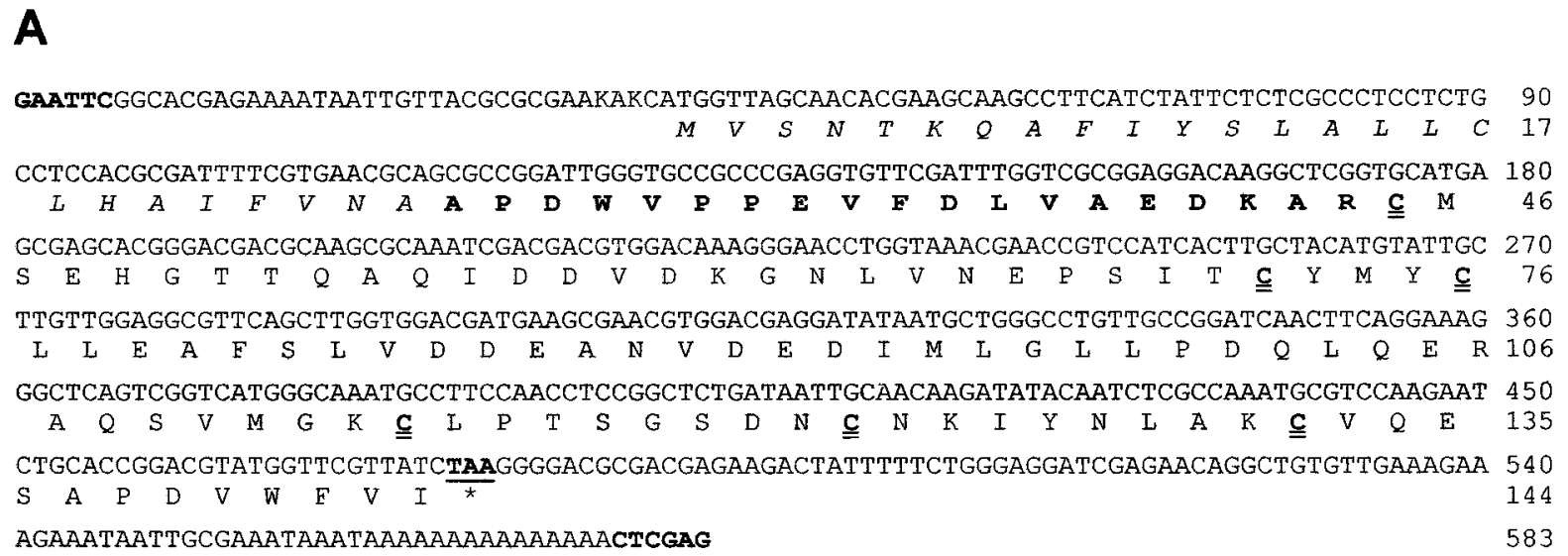

\section{B}

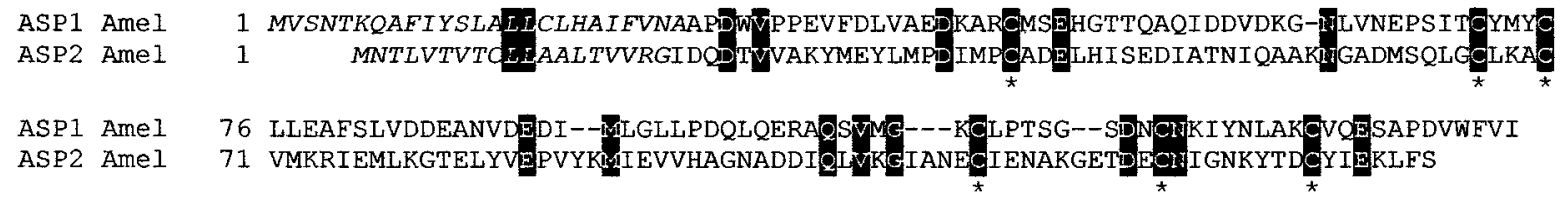

Figure 1. cDNA cloning and sequence of ASP1. A, Sequence of the 11M8A1 cDNA clone and the deduced amino acid sequence corresponding to ASP1. The nucleic acid and amino acid numbers are given to the right of each line. Amino acids identified by N-terminal sequencing (Danty et al., 1998) are in bold and the signal peptide in italics. The asterisk marks the stop codon, and cysteines are bold and double underlined. Cloning sites are in bold. B, Amino acid sequence alignment of ASP1 with ASP2. Signal sequences are in italics. Amino acid residues are dark-shaded when identical. Sequence alignment was optimized by introducing several gaps $(-)$. The asterisks mark the positions of conserved cysteine residues.

$290^{\circ} \mathrm{C}$ at $20^{\circ} \mathrm{C} / \mathrm{min}$. The carrier gas was helium at $8.7 \mathrm{ml} / \mathrm{min}$. Myristic (C14) methyl ester was used as internal standard for quantification.

\section{RESULTS}

\section{Molecular cloning and sequence analysis}

To characterize ASP1 by complete sequence determination, we prepared cDNA from adult drone antenna and generated a specific reverse transcription-PCR fragment with a $5^{\prime}$ primer deduced from the $\mathrm{N}$-terminal sequence of the natural protein. It was used to generate a specific DIG random-primed cDNA probe. An adult drone antennal cDNA library was generated and screened with this probe. The complete 11M8A1 cDNA clone corresponds to ASP1. A 144 amino acids polypeptide is encoded by the open reading frame (Fig. $1 A$ ). The comparison with the native protein indicates that the 25-residue $\mathrm{N}$-terminal sequence is cleaved after translation. The molar average mass 13,180.8 Da, calculated for the mature protein and assuming the formation of three disulfide bridges, was in perfect agreement with the measured molar mass $(13,180.2 \pm 1.6 \mathrm{Da})$ of the native protein (Danty et al., 1998). Southern blot hybridization on genomic DNA raised only one band, suggesting that ASP1a and ASP1b are encoded by a single identical gene (data not shown).

\section{Sequence comparison}

The complete amino acid sequence of ASP1 was compared with ASP2. The alignment was improved by introducing several insertions-deletions (Fig. $1 B$ ). ASP1 and ASP2 have only $15 \%$ amino acids in common but six cysteines in conserved positions, which are probably involved in the same disulfide bridge arrangement in both proteins. Sequence homology search showed that ASP1 is a new protein belonging to the family of insect OBPs. When comparing the primary sequence of mature proteins, the highest amino acid sequence identity was observed for antennal binding protein X from Antheraea pernyi (28\%), most of the other mem- bers of the family presenting approximately $16-24 \%$ amino acid sequence identity with ASP1 (Fig. 2). The six cysteines and their interval spacing are the most striking features shared by proteins belonging to this family, except for nonolfactory proteins of the tubular accessory sex glands of Tenebrio molitor, antifreeze protein from T. molitor, sericotropin from Galleria mellonella, and male-specific protein from Ceratitis capitata, which lack the second and the fifth ones. To reduce background and to increase the sensitivity to distant relationships between these divergent sequences, a search in BLOCKS database showed that ASP1 belongs to a group of sequences which have in common one to four blocks, which are short multialign ungapped segments corresponding to the most highly conserved regions of the proteins (Henikoff and Henikoff, 1994). ASP1 contains blocks 1, 3, and 4 in which four of the six cysteines are located. Thus, this group of proteins presenting three blocks in common might originate from the same ancestral gene.

\section{Location in olfactory sensilla}

ASP1 was previously isolated from antennal protein homogenates and was not detected in other tissues, such as legs, brain, and thorax (Danty et al., 1998). To confirm that ASP1 is specifically expressed in olfactory sensory organs, we analyzed its location by nonradioactive in situ hybridization (Fig. 3). In both worker and drone, ASP1 mRNA was found to be restricted to the antennal olfactory areas (third to tenth segments in the worker, third to eleventh in the drone). The shape of labeled cells could not be finely resolved in these experimental conditions, probably because of the large number of sensilla expressing ASP1, as previously observed for ASP2 in workers compared with the few groups of cells labeled in drone antenna (Danty et al., 1997). In drones, groups of cells expressing ASP1 were located in the auxiliary cell layer, close to sensilla placodea. In workers, assigna- 


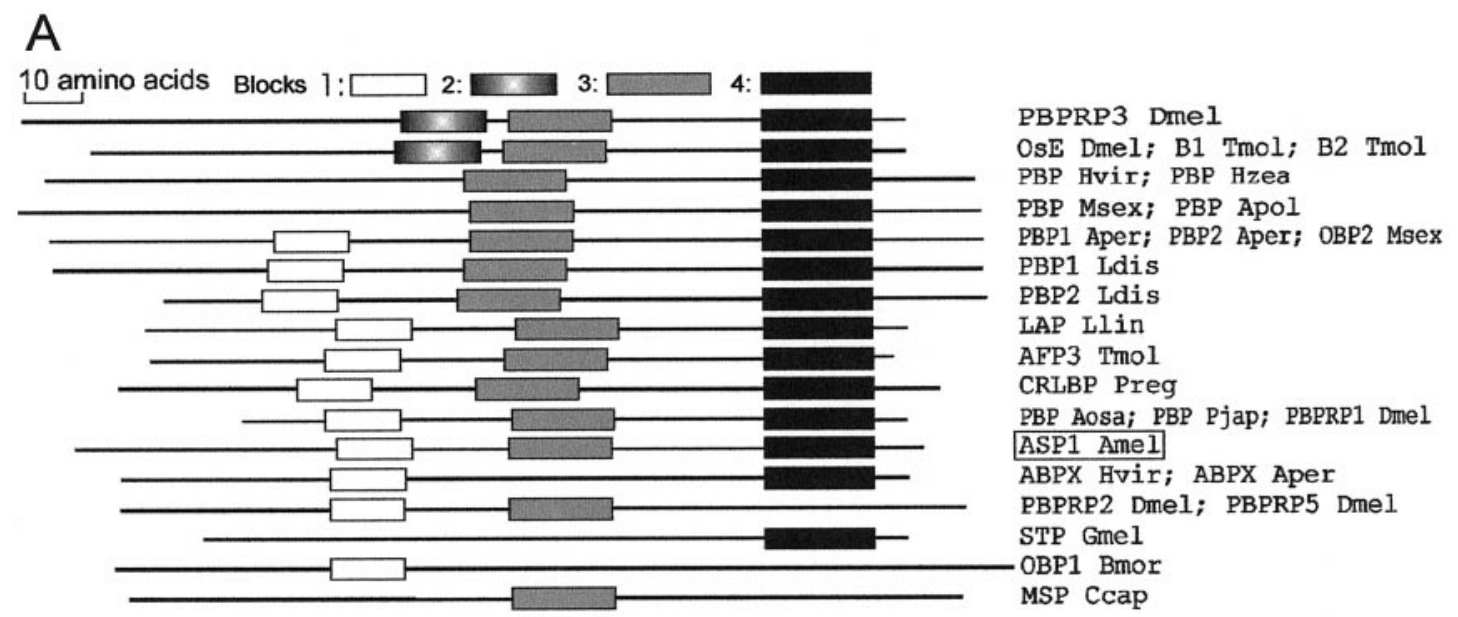

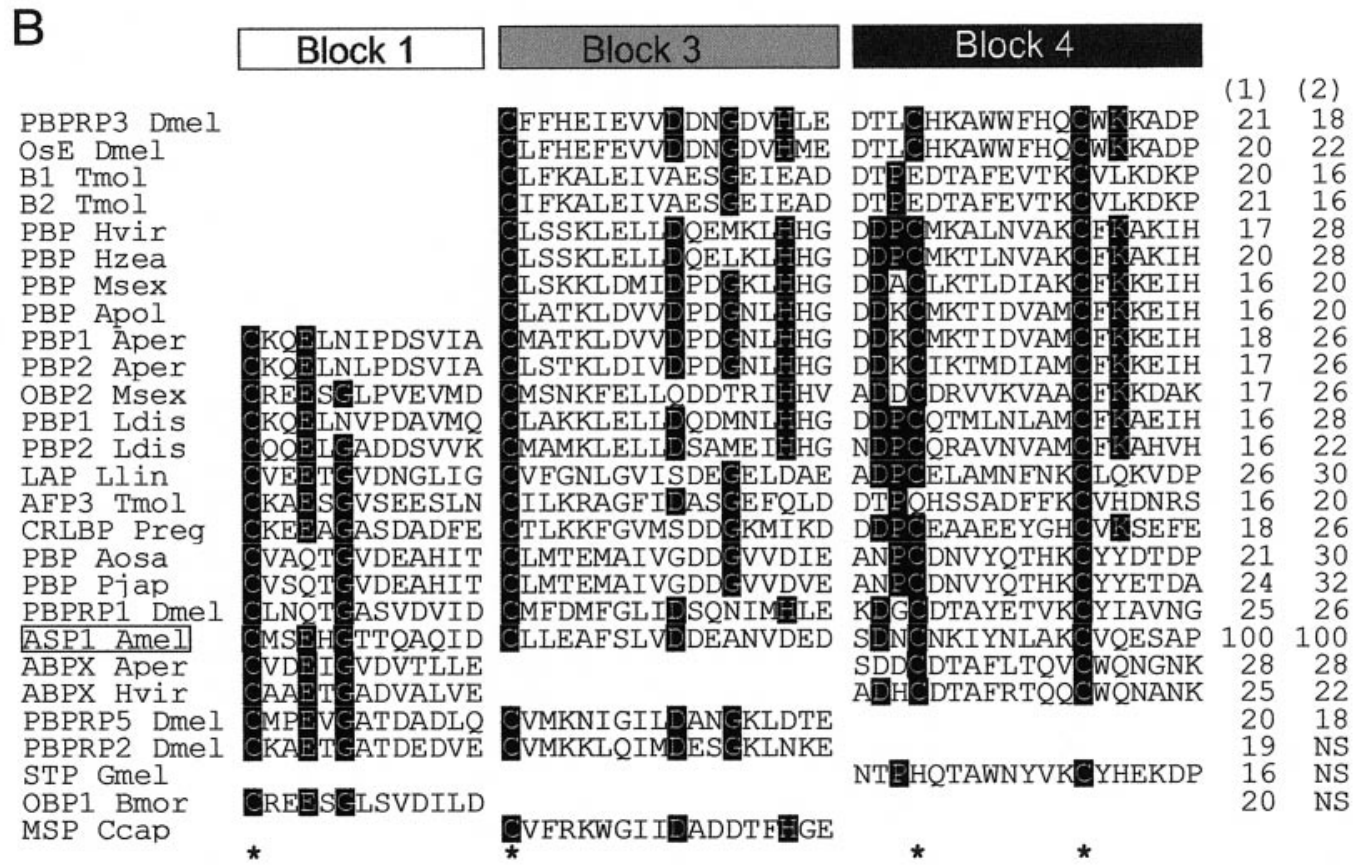

Figure 2. Amino acid sequence comparison of ASP1 with members of insect odorant-binding protein family by BLOCK Searcher. $A$, Graphical representation of proteins presenting blocks from the Prosite family of mealworm beetle B proteins. $B$, Sequence alignment of blocks using the BoxShade software. Amino acid residues are dark-shaded when identical to the BLOCK consensus. The asterisks mark the position of conserved cysteines. Percentages of sequence identity with ASP1 are reported from a global sequence comparison (column 1) and block comparison (column 2) by using a Blosum 50 matrix (Myers and Miller, 1988). Abbreviations and NCBI accession numbers are as follows: $A B P X A p e r$, antennal binding protein X from Antheraea pernyi (2597821); ABPX Hvir, from Heliothis virescens (2597955); AFP3 Tmol, antifreeze protein from Tenebrio molitor (785072); ASP1 Amel, antennal-specific protein from A. mellifera; B1 Tmol, B2 Tmol, proteins of the tubular accessory sex glands of T. molitor (I61691, 161693); CRLBP Preg, chemical-sense-related binding protein of labellar taste sensilla from Phormia regina (I042146); LAP Llin, antennal protein from Lygus lineolaris (3644030); MSP Ccap, male-specific protein from Ceratitis capitata (1894778); OBP1 Bmor, from Bombyx mori (2506473); OBP2 Msex, from Manduca sexta (400657); OsE Dmel, from Drosophila melanogaster (2494874); PBP Aosa, from Anomala osakana (3721996); PBP1 Aper, PBP2 Aper, from Antheraea pernyi (I255913, 1255915); PBP Apol, from A. polyphemus (226489); PBP Hvir, from Heliothis virescens (I255935); PBP Hzea, from Helicoverpa zea (3639083); PBP Msex, from Manduca sexta (I29675); PBP1 Ldis, PBP2 Ldis, from Limantria dispar (2444185, 2444187); PBP Pjap, from Popillia japonica (3721994); PBPRP1 Dmel, PBPRP2 Dmel, PBPRP3 Dmel, PBPRI5 Dmel, PBP-related proteins from D. melanogaster (454396, 454398, 454400, 454404); STP Gmel, sericotropin from Galleria mellonella (I146410). NS, Not significant.

tion of labeling to auxiliary cells of s. placodea was not possible because s. placodea and sensilla trichodea A are highly intermingled. However, like in drones, this result indicates high expression levels of ASP1 in the adult worker olfactory sensilla.

\section{Sex-specific developmental profiles}

In the honeybee, the biological effect of the queen pheromone depends on age and sex (Allan et al., 1987; Free, 1987). There- fore, the developmental profile of ASP1 and other antennal protein expression was analyzed by nondenaturing PAGE, in parallel for drone and worker, to determine the functional relationships between ASP1 expression and the development and maturation of the olfactory system.

In drones, ASP1a was first detected at $1 \mathrm{~d}$ before emergence (E1), as well as ASP2 and ASP3a (Fig. 4A). The highest amounts of these proteins were detected in newly emerged insects, and 


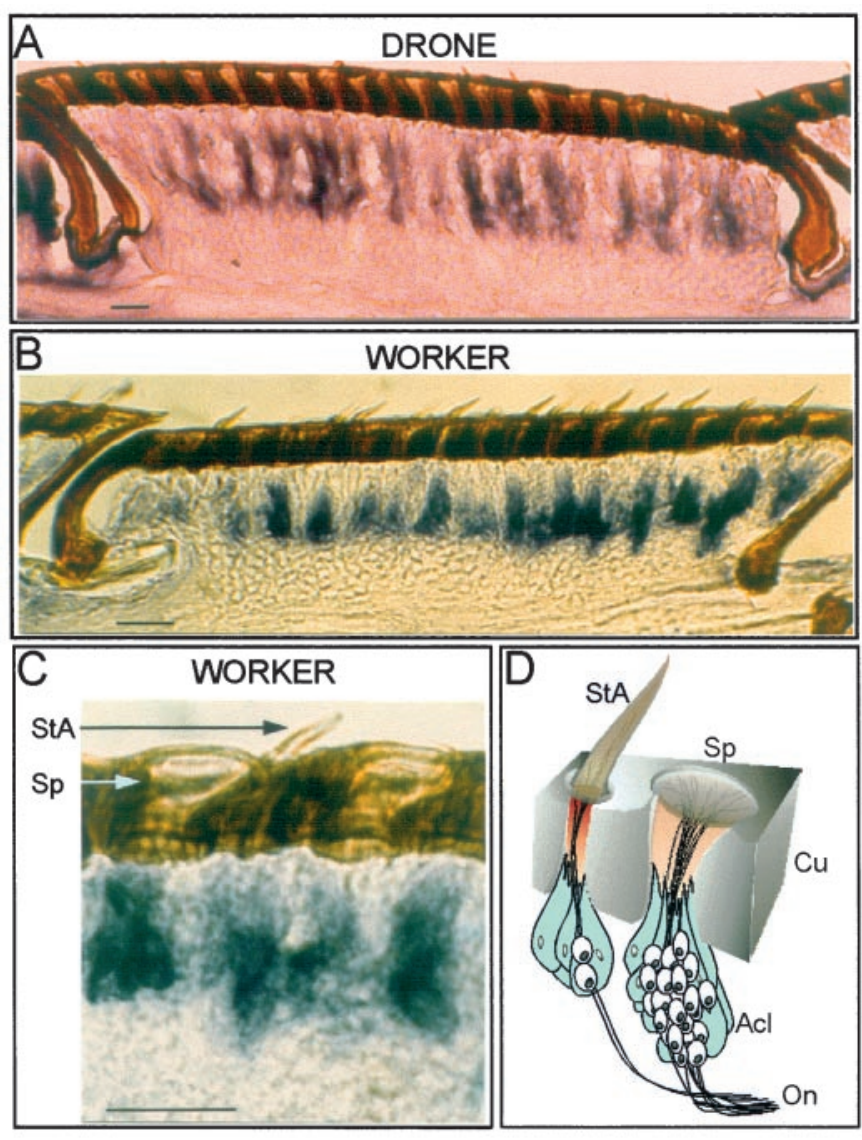

Figure 3. Localization of ASP1 mRNA in antennal structures. Longitudinal sections through one article hybridized with a DIG-labeled riboprobe and alkaline phosphatase detection. Labeled cells are in dark blue. Cuticular structures are naturally brown. A, Drone antenna with mainly $s$. placodea. $B, C$, Worker antenna with intermingled s. placodea and $s$. trichodea. D, Cellular organization of s. trichodea A and s. placodea redrawn from Schneider and Steinbrecht (1968). Scale bars, $20 \mu \mathrm{m}$. Acl, Auxiliary cell layer; $\mathrm{Cu}$, cuticle; $\mathrm{On}$, olfactory nerve; $\mathrm{Sp}$, sensilla placodea; StA, sensilla trichodea A.

then these levels were not significantly altered in adults. Remarkably, the ASP1b isoform became visible only between E+15 and $\mathrm{E}+19$ according to the various samples analyzed and was maintained in older insects. It was, however, always simultaneous with the apparent replacement of ASP3a by ASP3b, another small protein related to Drosophila olfactory-specific protein Os-D (Danty et al., 1998).

In workers, both behavioral and electrophysiological responses to a queen-head extract or a synthetic blend depend on age (Pham-Delègue et al., 1993). A temporal analysis of ASP1 expression was performed from $\mathrm{E}-5$ to $\mathrm{E}+14$ and in foragers (Fig. $4 B)$. Both ASP1 isoforms, as well as ASP2 and ASP3a, were first detectable in antennal homogenates at $E-1$. The amount of all these proteins increased to a plateau in 1-d-old insects, which did not significantly vary thereafter as estimated from the electrophoregram staining. A protein with an electrophoretic migration slightly longer than ASP3a was observed at E-5 and then disappeared at E-3. Edman sequencing revealed it was a novel sequence (EDDEALXKGGEK) without any homology with ASP3a or any known protein in sequence databases.
A
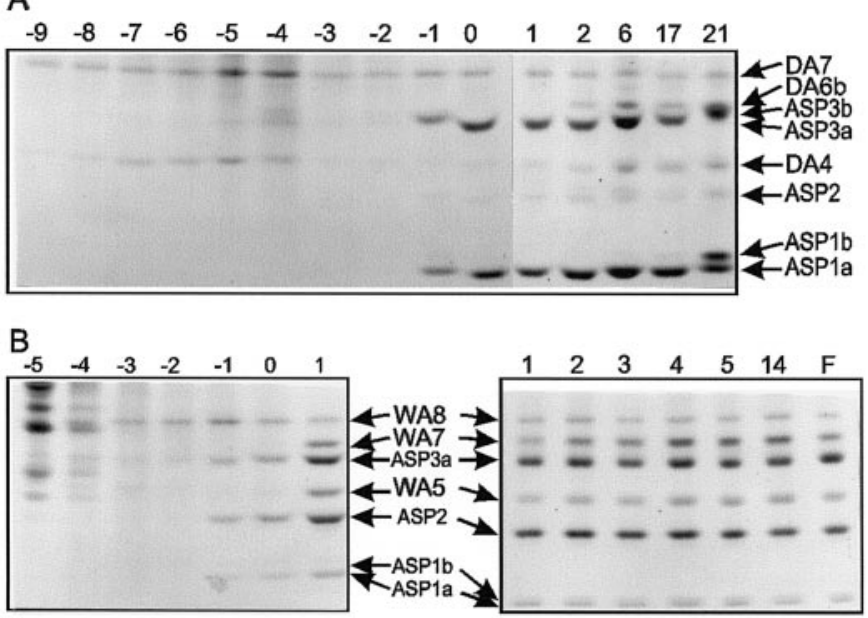

Figure 4. Postembryonic expression of antennal-specific proteins from drones $(A)$ and workers $(B)$ analyzed by nondenaturing PAGE. Emergence day $(O)$ was considered as the day-aging reference. Numbers above lanes indicate day before ( - ) and after emergence. Each lane corresponds to protein extracts from 20 antennae from pupae and adults raised in natural conditions. Gels have been cutoff and only show the very fast moving molecular species. ASP, Antennal-specific protein; $D A$, drone antennal protein; $F$, adult forager; $W A$, worker antennal protein.

\section{Heterologous expression and characterization of ASP1}

To evaluate its binding properties, ASP1 was heterologously expressed using the methylotrophic yeast $P$. pastoris. The protein ASP1 was secreted using its natural honeybee signal peptide under the control of the methanol-inducible alcohol oxidase $(A O X I)$ promoter. The recombinant protein was found to be the major component and eluted at $32 \%$ acetonitrile in reversedphase HPLC as the native protein (Danty et al., 1998). Samples of the expression medium supernatants, taken at various time intervals, were also analyzed by SDS-PAGE to determine the optimal induction time. Only the recombinant protein, migrating at $\sim 14$ kDa, was detectable by Serva Feinbiochemica blue-G staining. The electrophoretic profile (Fig. $5 A$ ) reveals the protein regularly accumulating up to $\sim 0.2 \mathrm{mg} / \mathrm{ml}$ over an expression period of $6 \mathrm{~d}$, whereas only traces of other proteins were detected. The clone with the highest level of ASP1 expression was chosen for largescale production in fermentation culture. After dialysis, the recombinant protein was purified by one step anion-exchange chromatography. Recombinant ASP1 was eluted as a single peak at $250 \mathrm{~mm} \mathrm{NaCl}$ in agreement with the calculated isoelectric point and migrated as a single $14 \mathrm{kDa}$ species on SDS-PAGE. $\mathrm{N}$-terminal sequencing, IS-MS, and reversed-phase chromatography confirmed that the recombinant protein ASP1 was purer than 95\% and in perfect agreement with expected features. Correct processing of the signal sequence was verified by $\mathrm{N}$-terminal analysis of purified ASP1. Based on the amount of residues released in each cycle of Edman degradation, the percentage of two N-terminal forms of ASP1 has been determined. We found that $95 \%$ of proteins had an $\mathrm{N}$-terminal sequence, in agreement with the native ASP1 amino acid sequence, whereas the other 5\% showed an amputation of the first two N-terminal amino acid residues. The natural insect signal peptide was then efficient for proper secretion of heterologous ASP1 in P. pastoris. The loss of the two or four first amino acids of a recombinant protein secreted by $P$. pastoris has already been observed (Zhu et al., 1996; Denton et al., 1998). It seems to result from the action of the 


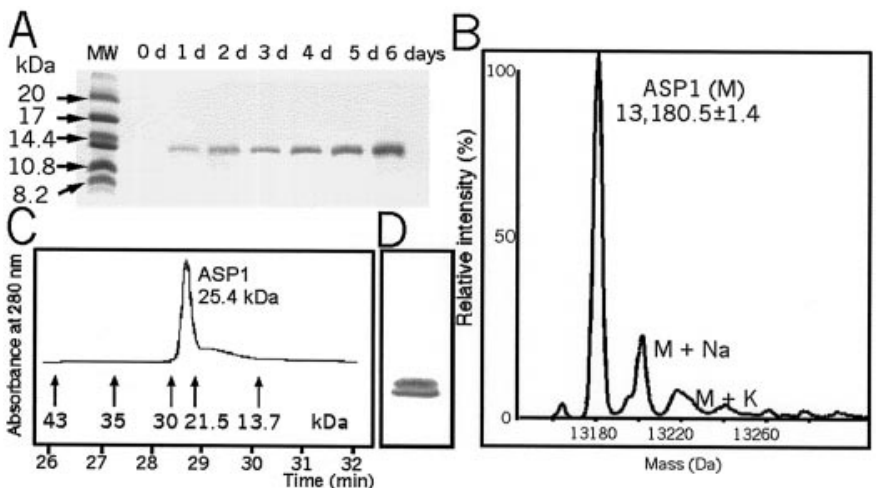

Figure 5. Biochemical analysis of recombinant ASP1 expressed in Pichia pastoris. A, SDS-PAGE analysis. Lane 1 shows standard (PMW kit; Pharmacia), and lanes 2-8 are $5 \mu \mathrm{l}$ aliquots of supernatants of 1- to 6-d-old cultures. $B$, Reconstructed ion-spray mass spectrum of ASP1 with $\mathrm{Na}$ and $\mathrm{K}$ adducts. $C$, Exclusion-diff usion chromatography of the recombinant protein. Bovine serum albumin $(43 \mathrm{kDa})$, chicken egg ovalbumin (35 kDa), bovine ribonuclease A (30 kDa), bovine $\alpha$-chymotrypsinogen A $(21.5 \mathrm{kDa})$, and horse cytochrome $c(13.7 \mathrm{kDa})$ were used as standards. The peak positions for the standard proteins are indicated by arrows under the graph with molecular weights. $D$, Nondenaturing PAGE analysis of $4.5 \mu \mathrm{g}$ of recombinant ASP1 after purification in $12.8 \%$ acrylamide gel and Serva Feinbiochemica blue-G staining.

diaminopeptidase Ste13. IS-MS on the recombinant protein secreted using its native leader sequence (Fig. $5 B$ ) showed a predominant peak, together with derivatives corresponding to $\mathrm{Na}$ and $\mathrm{K}$ adducts. The ASP1 mass was found to be 13,180.5 $\pm 1.4 \mathrm{Da}$ which is in perfect agreement with the measured molecular mass of the native honeybee protein, which is known to not undergo any posttranslational modification, in addition to the 25-residue signal peptide cleavage and formation of three disulfide bridges (Danty et al., 1998). The sulfhydryl titration using the method of Ellman (1958) confirmed that the three disulfide bridges were indeed formed. A content of $\sim 0.1$ thiol per protein was measured.

\section{ASP1 quaternary structure}

Calibrated exclusion-diff usion chromatography of purified ASP1 at $1.0 \mathrm{mg} / \mathrm{ml}$ gave an apparent molecular weight of $25.4 \mathrm{kDa}$, which is approximately twice the value obtained from mass spectrometry $(3,180.5 \pm 1.4)$, demonstrating dimerization of the recombinant protein (Fig. $5 C$ ). The ASP1 peak displayed some asymmetry, with a sharp leading edge and a tapering trailing edge. This peak shape is in agreement with that expected for dimers dissociating during gel filtration experiment. ASP1 was found to be a dimer at a concentration as low as $0.1 \mathrm{mg} / \mathrm{ml}$, corresponding to the limit of detection, indicating a high affinity of the monomers one for another $(>1 \mu \mathrm{M})$ In nondenaturing PAGE, the purified recombinant ASP1 migrated as two closed protein bands (Fig. 5D) as already observed with the natural proteins called isoforms ASP1a and ASP1b (Danty et al., 1998).

\section{Pheromone binding test}

To test the functional properties of ASP1, ligand-binding studies of the recombinant protein with the synthetic blend corresponding to the queen pheromone of the mandibular glands were performed. Two other proteins, bovine $\alpha$-lactalbumin and Phytophthora capsicein of similar molecular weight and isoelectric point were chosen as controls. In addition, ASP2, which was also expressed in P. pastoris (Briand et al., 1999), was also tested. The proteins were incubated with the synthetic blend of queen man-
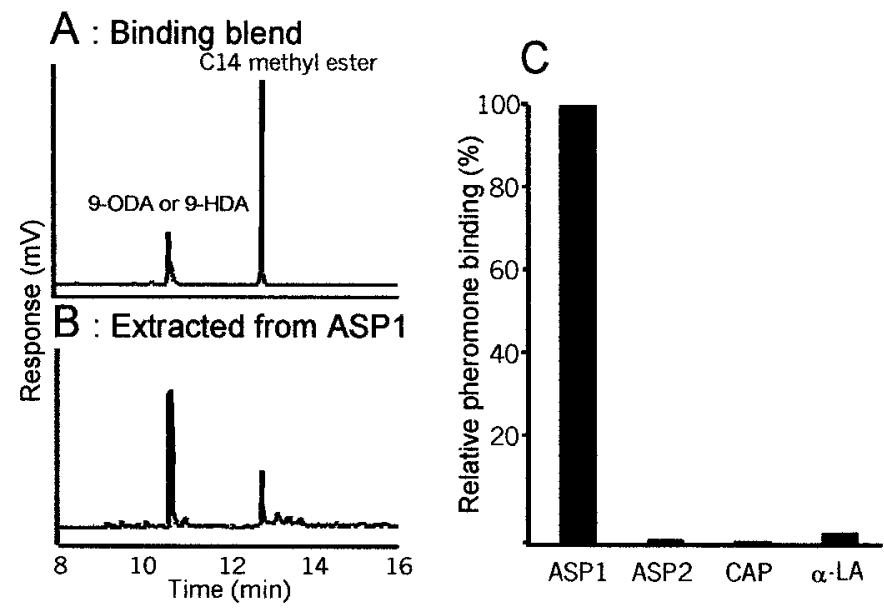

Figure 6. Binding of the synthetic queen pheromone complex to putative acceptors. $C A P$, Capsicein; $\alpha-L A, \alpha$-lactalbumin. Myristic methyl ester (C14) was used as internal standard for quantification. $A$, Gas chromatogram of the methylated synthetic pheromone. $B$, Gas chromatogram of the methylated ligand extracted from ASP1 after incubation with the synthetic pheromone. $C$, Relative proportions of synthetic pheromone compounds bound onto the different proteins.

dibular gland pheromone before precipitation with ammonium sulfate. The protein pellets were then extracted to analyze the ligand, which was further identified after methylation by gas chromatography. A prominent peak in the gas chromatogram was clearly assigned to any or both of the two major compounds of mandibular gland extract, i.e., the 9-ODA and the 9-HDA, which were indistinguishable from one another in the assay (Fig. 6A,B). Furthermore, in our conditions, neither $\alpha$-lactalbumin, capsicein nor ASP2 significantly bound the queen pheromone blend (Fig. 6C).

\section{DISCUSSION}

\section{ASP1 belongs to the multigenic family of insect OBPs}

As previously reported for ASP2 (Danty et al., 1997), ASP1 is a novel member of the insect OBP protein family, on the basis of sequence similarity and the presence of six cysteines in conserved positions. ASP1 was found to be divergent from ASP2, which suggests that these proteins bind different ligands. Such a functional difference has already been found in PBPs of closely related moth species (Prestwich et al., 1995). In addition, in lepidoptera, two subfamilies have been reported to be associated with olfaction, namely PBPs for sex pheromone and gOBPs for unknown ligands (Vogt et al., 1991). ASP1 and ASP2 could have such different roles, respectively.

Although different from ASP2, ASP1 does not share sequence similarity in common with vertebrate OBPs (Pelosi, 1994), known as lipocalins, a superfamily of proteins that have been also found in bacteria (Flower et al., 1995) and insects (Li and Riddiford, 1992). Despite their comparative functional and biochemical properties, olfactory proteins presenting significant sequence similarity to both insect and vertebrate OBPs have not yet been found. At the present time, the ancestral gene family of insect OBPs is still unknown.

\section{Cellular location of ASP1}

The antennae are involved in the detection of a variety of environmental odorous stimuli (Lacher, 1964). In the honeybee, olfactory receptor neurons are ensheathed in sensilla, namely the $s$. 
placodea and the $s$. trichodea, more precisely of type A (Lacher, 1964; Esslen and Kaissling, 1976). In drones and in workers, s. placodea are innervated by a large number of sensory neurons responding to various odor stimuli, including queen pheromone or its isolated major component 9-ODA (Kaissling and Renner, 1968; Ruttner and Kaissling, 1968; Vareschi, 1971; Akers and Getz, 1992). In holometabolous insects such as honeybee, each sensillum is formed by a set of auxiliary cells and sensory neurons (Steinbrecht, 1992). In workers, s. placodea are intermingled with s. trichodea, which represent, respectively, 55 and $45 \%$ of the olfactory sensilla, whereas in drone, s. placodea represent $94 \%$ of olfactory sensilla (Esslen and Kaissling, 1976). Compared with ASP2, which was previously reported to be expressed specifically in s. trichodea, ASP1 expression seems to be restricted to groups of cells corresponding to auxiliary cells of $s$. placodea, strongly suggesting a role of olfactory-binding protein for ASP1. This data are consistent with previous reports on moth PBPs (Steinbrecht, 1992) and Drosophila LUSH (Kim et al., 1998), indicating that OBPs are secreted by auxiliary cells in the sensillum lymph.

In drone, first, the majority of drone s. placodea expressed ASP1, and second, olfactory neurons responding to the queen pheromone are ensheathed in s. placodea. The higher sensitivity of drone than worker to queen pheromone or to 9-ODA suggests that they possess much more sensory neurons responding to these odors (Kaissling and Renner, 1968; Adler et al., 1972; Vetter and Visscher, 1997; Brockmann et al., 1998). Thus, we might expect that ASP1 is secreted by auxiliary cells associated with sensory neurons responding to queen pheromone in s. placodea, because ASP1 can interact with 9-ODA and/or 9-HDA.

\section{Pheromone binding properties of recombinant ASP1}

The recombinant ASP1 was found to be identical to the natural honeybee protein. This protein can be considered as a honeybee PBP because, in ligand binding experiments, it specifically interacted with one of the major components of the queen pheromone, 9-ODA and/or 9-HDA, or with both. ASP1 was observed to bind pheromone molecules so tightly that the complex could be precipitated without apparent dissociation. Moreover, this binding is highly specific because only a few percents of pheromone were found associated with the proteins used as controls. In contrast to ASP1, ASP2, which did not interact with any component of the honeybee synthetic queen pheromone, is probably a gOBP. This is the first binding data obtained for an insect olfactory-binding protein other than lepidoptera PBPs. A large number of such PBPs have been shown to bind components of the sex pheromone (Vogt and Riddiford, 1981; Vogt et al., 1989; Feixas et al., 1995; Pretswich et al., 1995; Maïbèche-Coisne et al., 1997). Pheromone binding properties of gOBPs are not so well documented. In Antherea polyphemus, females possess a putative gOBP instead of a male PBP, which was also able to bind the major component of the sex pheromone (Ziegelberger, 1995). In contrast, ASP1 was also found in lower amounts in the honeybee workers, which are capable to respond to the queen pheromone (Danty et al., 1998).

\section{Dimeric properties of ASP1}

The recombinant ASP1 was clearly observed by gel filtration to be a dimer in the micromolar range. At low concentrations, the recombinant protein migrated in nondenaturing PAGE as two bands, which might correspond to the natural ASP1a and ASP1b isoforms (Danty et al., 1998). These isoforms could therefore likely be the monomeric and dimeric forms of ASP1, because they differ from one another by less than a mass unit using mass spectrometry (Danty et al., 1998). In addition, the difference observed on the bases of electrophoretic mobility cannot be attributed to two different redox states because no free thiol has been measured with Ellman's reagent on the recombinant protein. Any other oxidation process would result in a mass variation of at least 16, which would be very clearly observed by mass spectrometry. This is opposite to the PBP of $A$. polyphemus, which has also been reported to be an homodimer (De Kramer and Hemberger, 1987), the two electrophoretic bands of which have been proposed to originate from different redox states of cysteine residues (Ziegelberger, 1995).

\section{Production of ASP1 in the developing and adult antenna}

In the honeybee worker, olfactory neuron functional maturation starts at $\sim 2 \mathrm{~d}$ before emergence (Masson and Arnold, 1984), just before the beginning of ASP1 and ASP2 production, which thus might reflect the maturation of olfactory sensilla. In drone, the electrophoretic profile of ASP1 was surprisingly modified in $>1$ week-old drones, even if the main difference was detected in older insects. Compared with in vitro ASP1 production, ASP1a could be a monomeric form first appearing at low concentration when sensilla maturation occurs, and ASP1b could be the homodimer formed when the concentration increases in adults older than 1 week. Sexual maturation occurs between E+9 and E+23, and queen pheromone does not become behaviorally relevant for mate attraction until this maturation process (Ruttner, 1966; Vetter and Visscher, 1997). When comparing samples from adults, we previously estimated that, in 6- to 17-d-old adults, drones possess approximately five times more ASP1 than workers (Danty et al., 1998), as drones possess also approximately five times more sensory neurons than workers (Esslen and Kaissling, 1976). We may consider that between $1 \mathrm{~d}$ before emergence and at least $2 \mathrm{~d}$ after emergence, ASP1 is still much more abundant in drones than in workers. However, the putative dimer was detected at any age in workers, although only as a putative monomer during this period in drones. Because the dimerization of ASP1 was spontaneously observed by in vitro production, one might expect that, in drones, a physiological mechanism might affect the putative dimerization of ASP1 until sexual maturity, possibly by controlling the concentration or the biochemical environment of ASP1 in the sensillum lymph. The redox shift hypothesis supporting the view of a biochemical modification of PBP after pheromone binding (Ziegelberger, 1995) cannot explain these data, because the absence of queen during drone development had no significant effect on the time course of ASP1 (not shown).

\section{Role of ASP1 in honeybee olfaction}

In a given species, several members of the insect OBP family are known to present differential binding properties and/or associate with distinct olfactory cells (Pelosi and Maida, 1995). Such a conclusion can be drawn about the honeybee in which we have distinguished a PBP (ASP1) able to bind components of the queen pheromone, opposite to ASP2, a putative gOBP. At present, there is only one demonstration of a physiological role for a gOBP, the alcohol-binding protein LUSH in D. melanogaster (Kim et al., 1998). A disruption of the protein gene causes a drastic effect on behavior, which is restored when a wild-type copy of the gene is introduced into mutant fruit flies. The authors suggested that LUSH might be required to activate a small subset of olfactory neurons mediating chemoavoidance rather than solubilization or desensitization. In light of these data, the existence 
of finely tuned sensory neuron responses to 9-ODA could be related to the role of this molecule in the honeybee society, with different behavioral effects on workers and drones. How this sexual diversity is encoded by the olfactory system is now under current investigation by analyzing the properties of ASP1 in both in vitro and in vivo approaches.

\section{REFERENCES}

Adler VE, Doolittle RE, Shimanuki H, Jacobson M (1972) Electrophysiological screening of queen substance and analogues for attraction to drone, queen and worker honey bees. J Econ Entomol 66:33-36.

Akers RP, Getz WM (1992) A test of identified response classes among olfactory receptor neurons in the honey bee worker. Chem Senses 17:191-209.

Allan SA, Slessor KN, Winston ML, King GGS (1987) The influence of age and task specialization on the production and perception of honey bee pheromones. J Insect Physiol 33:917-922.

Altschul S, Gish W, Miller W, Myers E, Lipman D (1990) Basic local alignment search tool. J Mol Biol 215:403-410.

Briand L, Perez V, Huet J-C, Danty E, Masson C, Pernollet J-C (1999) Optimization of the production of a honeybee odorant-binding protein by Pichia pastoris. Protein Expr Purif 15:362-369.

Brockmann A, Brückner D, Crewe RM (1998) The EAG response spectra of workers and drones to queen honeybee mandibular gland components: the evolution of a social signal. Naturwissenschaften 85:283-285.

Danty E, Michard-Vanhée C, Huet J-C, Genecque E, Pernollet J-C, Masson C (1997) Biochemical characterization, molecular cloning and localization of a putative odorant-binding protein in the honey bee Apis mellifera L. FEBS Lett 414:595-598.

Danty E, Arnold G, Huet J-C, Huet D, Masson C, Pernollet J-C (1998) Separation, characterization and sexual heterogeneity of multiple putative odorant-binding proteins in the honeybee Apis mellifera L. (Hymenoptera: Apidea). Chem Senses 23:83-91.

De Kramer J, Hemberger J (1987) The neurobiology of pheromone reception. In: Pheromone biochemistry (Prestwich GD, Blomquist GJ, eds), pp 433-472. New York: Academic.

Denton H, Smith M, Husi H, Uhrin D, Barlow P, Batt C, Sawyer L (1998) Isotopically labeled bovine $\beta$-lactoglobulin for NMR studies expressed in Pichia pastoris. Protein Expr Purif 14:97-103.

Ellman GL (1958) A colorimetric method for determining low concentrations of mercaptans. Arch Biochem Biophys 74:443-450.

Esslen J, Kaissling KE (1976) Zahl und Verteilung Antennaler Sensillen bei der Honigbiene (Apis mellifera L.). Zoomorphologie 83:227-251.

Feixas J, Prestwich GD, Guerrero A (1995) Ligand specificity of pheromone-binding proteins of the processionary moth. Eur J Biochem 234:521-526.

Flower DR, Sansom CE, Beck ME, Attwood TK (1995) The first procaryotic lipocalins. Trends Biochem Sci 20:498-499.

Free JB (1987) Pheromones of social bees. London: Chapman and Hall.

Gish W, Strates J (1993) Identification of protein coding regions in database similarity search. Nat Genet 3:266-272.

Henikoff D, Henikoff JG (1994) Protein family classification based on searching a database of blocks. Genomics 19:97-107.

Hildebrand JG, Shepherd GM (1997) Mechanisms of olfactory discrimination: converging evidence for common principles across phyla. Annu Rev Neurosci 20:595-631.

Jay SJ (1963) Prepupal and pupal ecdyses of the honeybee. J Apicult Res 1:14-18.

Kaissling KE, Renner M (1968) Antennae Rezeptoren für Queen Substance und Sterzelduft bei der Honigbiene. Z vergl Physiol 59:357-361.

Kim MS, Repp A, Smith DP (1998) LUSH odorant-binding protein mediates chemosensory responses to alcohols in Drosophila melanogaster. Genetics 150:711-721.

Lacher V (1964) Elektrophysiologische untersuchungen an einzelnen Rezeptoren für Geruch, Kholendioxyd, Luftfeuchtigkeit und Temperatur auf den Antennen der Arbeitsbiene und der Drohne (Apis mellifica L.). Z vergl Physiol 48:587-623.

Laemmli UK (1970) Cleavage of structural proteins during assembly of the head of bacteriophage T4. Nature 227:680-682.

Li W, Riddiford LM (1992) The two duplicated insecticyanin genes, ins-a and ins-b are differentially expressed in the tobacco hornworm, Manduca sexta. Nucleic Acids Res 22:2945-2950.

Maïbèche-Coisne M, Sobrio F, Delaunay T, Lettere M, Dubroca J, Jacquin-Joly E, Nagnan-Le Meillour P (1997) Pheromone-binding proteins of the moth Mamestra brassicae: specificity of ligand binding. Insect Biochem Mol Biol 27:213-221.

Maleszka R, Stange G (1997) Molecular cloning, by a novel approach, of a cDNA encoding a putative olfactory protein in the labial palps of the moth Cactoblastis cactorum. Gene 202:39-43.

Masson C, Arnold G (1984) Ontogeny, maturation and plasticity of the olfactory system in the workerbee. J Insect Physiol 30:7-14.

Masson C, Mustaparta H (1990) Chemical information processing in the olfactory system of insects. Physiol Rev 70:199-245.

Masson C, Pham-Delègue M-H, Fonta C, Gascuel J, Arnold G, Nicolas G, Kersberg M (1993) Recent advances in the concept of adaptation to natural odour signals in the honeybee, Apis mellifera. Apidologie 24:169-194.

McKenna MP, Hekmat-Scafe DS, Gaines P, Carlson JR (1994) Putative Drosophila pheromone-binding proteins expressed in a subregion of the olfactory system. J Biol Chem 269:16340-16347.

Myers E, Miller W (1988) Optimal alignments in linear space. Comput Appl Biosci 4:11-17.

Pelosi P (1994) Odorant-binding proteins. Crit Rev Biochem Mol Biol 29:199-228.

Pelosi P, Maida R (1995) Odorant-binding proteins in insects. Comp Biochem Physiol 111B:503-514.

Pernollet J-C, Sallantin M, Sallé-Tourne M, Huet J-C (1993) Elicitin isoforms from seven Phytophtora species: comparison of their physicochemical properties and toxicity to tobacco and other plant species. Physiol Mol Plant 42:53-67.

Pham-Delègue M-H, Trouiller J, Caillaud M, Roger B, Masson C (1993) Effect of queen pheromone on worker bees of different ages: behavioural and electrophysiological responses. Apidologie 24:267-281.

Pikielny CW, Hasan G, Rouyer F, Rosbash M (1994) Members of a family of Drosophila putative odorant-binding proteins are expressed in different subsets of olfactory hairs. Neuron 12:35-49.

Prestwich GD, Du G, Laforest S (1995) How is pheromone specificity encoded in proteins? Chem Senses 20:461-469.

Rembold H, Kremer J-P, Ulrich G (1980) Characterization of postembryonic developmental stages of the female castes of the honey bee, Apis mellifera L. Apidologie 11:29-38.

Ruttner F (1966) The life and flight activity of drones. Bee World 47:93-100.

Ruttner F, Kaissling KE (1968) Über die interspezifische Wirkung des Sexuallockstoffes von Apis mellifica und Apis cerana. Z vergl Physiol 59:362-370.

Sallantin M, Huet J-C, Demarteau C, Pernollet J-C (1990) Reassessment of commercially available molecular weight standards for peptide sodium dodecyl sulfate-polyacrylamide gel electrophoresis using electroblotting and microsequencing. Electrophoresis 11:34-36.

Schägger H, von Jagow G (1987) Tricine-sodium dodecyl sulfatepolyacrylamide gel electrophoresis for the separation of proteins in the range from $1 \mathrm{kDa}$ to $100 \mathrm{kDa}$. Anal Biochem 166:368-379.

Schneider D, Steinbrecht RA (1968) Checklist of insect olfactory sensilla. Symp Zool Soc Lond 23:279-297.

Slessor KN, Kalinski L-A, King GGS, Borden JH, Winston ML (1988) Semiochemicals basis of the retinue response to queen honey bees. Nature 332:354-356.

Steinbrecht RA (1992) Experimental morphology of insect olfaction: tracer studies, $\mathrm{x}$-ray microanalysis, autoradiography and immunocytochemistry with silkmoth antennae. Microsc Res Tech 22:336-350.

Vareschi E (1971) Duftunterscheidung bei der Honigbiene-EinzelzellAbleitungen und Verhalten reaktionen. Z vergl Physiol. 75:143-173.

Vetter RS, Visscher PK (1997) Influence of age on antennal response of male honey bees, Apis mellifera, to queen mandibular pheromone and alarm pheromone component. J Chem Ecol 23:1867-1880.

Vogt RG, Riddiford LM (1981) Pheromone binding and inactivation by moth antenna. Nature 293:161-163.

Vogt RG, Köhne AC, Dubnau JT, Prestwich GD (1989) Expression of pheromone-binding proteins during antennal development in the gypsy moth Lymantria dispar. J Neurosci 9:3332-3346.

Vogt RG, Prestwich GD, Lerner MR (1991) Odorant-binding protein subfamilies associate with distinct classes of olfactory receptor neurons in insects. J Neurobiol 22:74-84.

Zhu A, Monahan C, Wang Z-K, Goldstein J (1996) Expression, purification and characterization of recombinant $N$-acetylgalactosaminidase produced in the yeast Pichia pastoris. Protein Expr Purif 8:456-462.

Ziegelberger G (1995) Redox-shift of the pheromone-binding protein in the silkmoth Antherea polyphemus. Eur J Biochem 232:706-711. 